\title{
Reverse Threshold Model Theory for Analysis Agricultural Data
}

\author{
Supat Faarungsang* \\ Department of Animal Science, Faculty of Agriculture, Kasetsart University, Thailand
}

Submission: March 09,2018; Published: April 11, 2018

"Corresponding author: Supat Faarungsang, Department of Animal Science, Faculty of Agriculture, Kasetsart University, Thailand, Email: goo555@gmail.com

\begin{abstract}
Most of agricultural data was wrongly analysis under Fisherian statistics (FS) because data is too small and normality assumption cannot be reached. Reverse Threshold Model Theory (RTMT) was introduced to solve the problems because under RTMT there is no restriction on data size and normality assumption. Review of RTMT and conventional statistical method was done.
\end{abstract}

Keywords: Matvec; Computer simulation; Statistical method

\section{Introduction}

Good overview of statistical analysis was done [1]. His research was extended from a picture given on website. (http:// cse.niaes.affrc.go.jp/minaka/R/images/Manada2004-large. jpg). He gave a simplified statistical mandala to imply that Fisherian statistics (FS) can be applied only in very narrowed domain of data. While today analysis use it widely wrong without knowing correctly assumption. Most of data today especially on agricultural research composed of too small data to be used under FS. It should be analyzed under Bayesian statistics (BS) or non parametric statistics (NS). On another huge data size, there exist multivariate statistics (MS) and mixed models statistics (MMS).

Mendel analysis his results using counting methods while FS assume that traits compose of infinite factors so he propose normality and analyze it under t-test or F-test [2,3]. While recently some journal stop using $\mathrm{P}$ value but most publication continue to use it in the same way defective Windows dominated to Linux.

Faarungsang using computer simulation techniques to teach students in Kasetsart university to understand nature of data size, means and variances on t-test and F-test [4]. It was concluded that $\mathrm{P}$ value is not a good value to jump to conclusion of statistical hypothesis. Later the author found by accident that better method name "Reverse Threshold Model Theory (RTMT)" is a better alternative to get rid off classical statistical method defective on violation of normality.

\section{Objective}

An objective of writing this paper is to give a simple method for poor farmers to analyze their data using RTMT.

\section{Review of selected events happen in statistical methods}

Fisher was honor to be father of statistics while Yate was recognized as mother. The same incidence happen in Thailand in 1962, Dr. Charan Chantalakhana was honor to be father of Thai statistician while he was an agricultural scientist in the same manner Fisher was. All of them bold on classical statistician in which bold on $\mathrm{P}$ value under F-test or t-test. Most papers in agricultural research applied their methods without awareness of normality assumption and data size. Later multivariate analysis was introduced to Kasetsart University but rare papers using it. Other method namely Bayesian and non-parametric statistics fall in to the same fate.

Faarungsang [5] fall in to the same trap of FS and try to fit maximum R-square in model using partial regression within class and become origin of today Random Regression Model (RRM) which is derive from Best Linear Unbiased Prediction (BLUP) by assuming that sire milk curve on an individual are different.

In 1995 Faarungsang start different way of thinking and introduced new class using Matvec Wang [6] and R (R, 2018) as a tool to let students to understand nature of statistical analysis. Several data set generated by Matvec were given to students and 
let them analyzed it by using Matvec and R under General Linear Model (GLM). It was concluded that with the same means and same variance, data size had serious effect to $P$ value. So, using $P$ value can lead to serious mistake in statistical hypothesis conclusion. In his classes students can bring any books, dictionaries, and friends for helping them to solve the problem. They should make R scripts (R, 2018) and accompanying explanatory documents as their answers to the problems in his final examination.

In 2009, Faarungsang accidentally found new method namely RTMT have higher efficiency to analyze internet data between home Internet Service Provider (ISP) compare to University ISP.

Under poor farmers conditions, their problems are different from what researcher interest and do not need complicated analysis and measurement. For example, poor farmers with a small land may want to cultivate Yardlong Bean over their water tunnel. With this goal they did not have to rely on any papers but perform their own small home made experiment. If they can have 20 fruits without defect then under RTMT it can be $100 \%$ to certify that their method work completely and can continue to do it again and again until condition of plant growth were changed $[7,8]$.

Reason poor farmers can only count success fruit up to only 20 because under RTMT complicated measurement is not exist and results are free from random errors measurement.

In history, TV channels, Newspaper dominated most events happened in the world but after internet happened and everyone do have several Mobile Application Devices (MAD) the world event become turning into an individual hands. The same thing happen to research today, after RTMT was born they have no need to depend on respectable researchers but poor farmers themselves can perform their own simple experiment to solve their own specific problems under their own agricultural practice conditions.

\section{References}

1. Toquenaka Y (2016) How to walk on statistical mandalas as a population ecologist. Popul Econ 58(1): 3-8.

2. Mendel G (1866) Versuche uber Pflanzen-Hybriden. Verhandludgen des naturforchenden Vereines Brunn 4: 18-65.

3. Fisher RA (1918) The correlation between relatives on supposition of Mendelian inheritance. Trans R Soc Edinb 59: 399-433.

4. Faarungsang S (2006) One Laptop Per Child (OLPC): a self-sufficient and sustainable system for teaching and learning animal science classes. In Proceedings of the 4th Agricultural Graduate Conference. December 2006, Department of Animal Science, Faculty of Agriculture, Chiengmai University, Thailand, pp. 90-99.

5. Faarungsang S (1979) Genetic parameters of weights and gains up to 56 days of swine. MS Thesis, Kasetsart University, Bangkok, Thailand.

6. Wang T (1990) Matvec User's Guide. University of Illinois, Champaign, IL, USA.

7. Faarungsang S, Nakthong S (2017) Efficiency using computer simulation of Reverse Threshold Model Theory on assessing a "One Laptop Per Child" computer versus desktop computer. Agric \& Nat Res 51(2): 131-136.

8. Core Team R (2014) R: a language and environment for statistical computing. R foundation for statistical computing, Vienna, Austria.

\section{Your next submission with Juniper Publishers} will reach you the below assets

- Quality Editorial service

- Swift Peer Review

- Reprints availability

- E-prints Service

- Manuscript Podcast for convenient understanding

- Global attainment for your research

- Manuscript accessibility in different formats

( Pdf, E-pub, Full Text, Audio)

- Unceasing customer service

Track the below URL for one-step submission https://juniperpublishers.com/online-submission.php 